\title{
Trans Terminology and Definitions in Research on Transphobia: A conceptual review
}

Terminología y definiciones trans en la investigación sobre transfobia: una revisión conceptual

\author{
Sara Aguirre-Sánchez-Beato \\ Université libre de Bruxelles
}

\begin{abstract}
The understanding of transphobia and discrimination against trans people depends on the definition itself of 'trans people'. However, trans terminology is not unambiguous. In this paper I identify terms and definitions commonly used in contemporary scientific research on transphobia (2005-2016) in English, French, Spanish and Portuguese. A review of literature and a qualitative content analysis were carried out. Eight themes were identified within the definitions: identity, expression, sex-gender binary, man-woman binary, body modifications, medical diagnosis, anti-pathological claim and political claim. Different terms are used to emphasise different definitions. I argue that the polysemy of trans terminology raises a concern for studies relying on a fixed and robust definition of trans people. Moreover, research should pay attention to the definitions that it establishes and their effects. Examining gender norms and relying on trans people's self-definitions seems a more fertile approach to understanding transphobia.
\end{abstract}

Keywords: Transgender; Transsexual; Transphobia; Review

\section{Resumen}

La comprensión de la transfobia y discriminación hacia las personas trans depende de la propia definición de 'persona trans'. Sin embargo, la terminología trans no es unívoca. En este artículo identifico términos y definiciones usadas habitualmente en la investigación científica actual sobre transfobia (2005-2016) en inglés, francés, español y portugués. Se realizó una revisión de literatura y un análisis de contenido cualitativo. Se identificaron ocho temas definitorios: identidad, expresión, binarismo sexo-género, binarismo hombremujer, modificaciones corporales, diagnóstico médico, reivindicación anti-patológica y reivindicación política. Diferentes términos son usados para enfatizar diferentes definiciones. Alego que la polisemia de la terminología trans plantea una dificultad para los estudios que usan una definición fija y fuerte. Además, es necesario que la investigación reflexione sobre las definiciones que establece y sus efectos. Examinar las normas de género y contar con las definiciones de las propias personas trans parece una perspectiva más fructífera para comprender la transfobia.

Palabras clave: Transgénero; Transexual: Transfobia; Revisión 


\section{Introduction}

Figures concerning transphobia, violence and discrimination against trans people ${ }^{1}$ all over the world are alarming. According to the survey carried out by the European Union Agency for Fundamental Rights, (2014), 54\% of trans respondents reported discrimination and harassment in the 12 months prior to the survey. Furthermore, 2,115 killings of trans people were reported from 2008 to 2016 worldwide (Transgender Europe, 2016).

Research on transphobia and discrimination against trans people is thus essential to understand and address the problem. However, describing the nature of transphobia and discrimination against this group is not straightforward: it very much depends on the definition itself of trans people (Bettcher, 2014). For example, if trans people are defined as people 'who violate gender norms' or 'the gender binary', then transphobia is a negative response against those violations. In this regard, a few words of warning are needed for research in this field.

First, there is a range of terms to refer to this population and a single term may have different meanings. 'Transgender' and 'transsexual', main terms employed in research, are used to denote different aspects of identities and experiences (Elliot, 2009). Second, terminology used to refer to trans people and its specific meaning may vary in different linguistic contexts. Although the field of Trans Studies was originally developed in the AngloSaxon world (Stryker \& Whittle, 2006), it is an emerging research field in Latin America (e.g. Franco \& Cicillini, 2015; Martínez-Guzmán, 2015; Molina Rodríguez, Guzmán Cervantes \& Martínez-Guzmán, 2015) and continental Europe (e.g. Alessandrin, 2016; Espineira, 2014; Missé \& Coll-Planas, 2010; Platero Méndez, 2014). And third, knowledge produced by research contributes to establishing the criteria through which a phenomenon is understood and analysed (Doménech \& Íñiguez-Rueda, 2002), i.e. the way scholarly work defines

\footnotetext{
1 'Trans people' is used in this paper as umbrella term. A conceptual definition is not initially offered because the aim of the paper is precisely to identify and discuss the conceptual definitions of trans people found in the literature. A working definition is suggested in the Discussion and conclusions section.
}

trans people can contribute to instituting the category itself.

In view of the above and to contribute to future international research on the topic, the objective of this paper is to identify the terms and definitions commonly used to refer to trans people in contemporary scientific research (2005-2016) dealing with transphobia and discrimination against trans people in four languages: English, French, Spanish and Portuguese.

For this purpose, a review of the literature and a qualitative content analysis were carried out. In the section 'Method, procedure and corpus' I describe the procedure used to identify the documents, the characteristics of the selected corpus and the methodology of analysis. The section 'Results: Trans terminology and definitions' presents the outcomes of the analysis. In the 'Discussion and conclusions' section, I address the implications stemming from the results and I present some suggestions for future research on the topic.

\section{Method, procedure and corpus}

A literature review is an explicit design that helps structure a research field and identify its conceptual content by pinpointing patterns, themes and issues (Seuring, Müller, Westhaus, \& Morana, 2005). Its methodological basis is usually a document analysis conducted as a content analysis. It comprises the following steps: material collection, descriptive analysis, (deductive or inductive) theme selection and material analysis (Seuring et al., 2005).

The material collection was carried out through a search of the following databases: Scopus, JSTOR, DOAJ, Redalyc and CAIRN. Scopus and JSTOR are relevant international databases containing documents mainly in English. DOAJ includes open access journals that may not be incorporated in the first two. Redalyc and CAIRN are regional databases. Redalyc is an important database from Latin America, Spain and Portugal including articles in Spanish and Portuguese. CAIRN is the French-speaking referring database for the human and social sciences.

I looked for articles, book chapters and books published from January 2005 to September 2016 in the field of human and social sciences. 


\begin{tabular}{|c|c|c|c|c|c|c|}
\hline Keyword(s) 1 & Keyword(s) 2 & Scopus & JSTOR & DOAJ & Redalyc & CAIRN \\
\hline \multicolumn{2}{|c|}{ Transphobia } & 136 & 41 & 19 & 153 & 4 \\
\hline \multirow{3}{*}{ 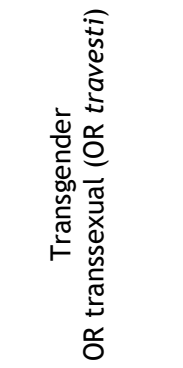 } & Discrimination & 424 & 612 & 49 & 504 & 21 \\
\hline & $\begin{array}{c}\text { Prejudice } \\
\text { OR stereotype }\end{array}$ & 130 & 511 & 7 & 688 & 0 \\
\hline & Exclusion & 77 & 176 & 19 & 440 & 0 \\
\hline
\end{tabular}

Table 1. Total number of documents found per database and keywords (all languages)

The keywords and Boolean operators used to identify the documents were: 1) the term 'transphobia'; 2) 'discrimination'/ 'stereotypes or prejudices' / 'exclusion' combined with the main terms 'transgender or transsexual'. In Spanish and Portuguese the term 'travesti' ${ }^{2}$ was also used because, although it is barely employed as the main term to refer to trans people in the Anglo-Saxon world nowadays, it is often used in the Latin American context. The keywords were entered in English, French, Spanish and Portuguese into the five databases. They were searched for in the abstract when this option was available ${ }^{3}$ or in the full text when it was not ${ }^{4}$. The number of documents found per database is shown in table 1.

After eliminating all duplicate documents $(\mathrm{N}=413)$, I read the title, abstract and introduction of the documents, using the following criteria for their final inclusion in the review:

- Documents written in English, French, Spanish or Portuguese.

- Documents whose main objective is to explain transphobia/exclusion/discrimination against trans people. I therefore excluded: a) documents exclusively documenting this

\footnotetext{
2 Literally 'transvestite' in English (but it is used with a different meaning in Latin America).

${ }^{3}$ Scopus and CAIRN.

${ }^{4}$ DOAJ and Redalyc do not have this option and most of the documents in JSTOR do not have an abstract. This explains the particularly high number of documents found in JSTOR and Redalyc.
}

type of discrimination (i.e. percentages of trans people reporting discrimination) and/or addressing its consequences (i.e. health impacts, psychological distress) and b) documents in which trans people are only mentioned under the LGBT acronym or sexual minority umbrella but not really targeted.

The final corpus covered 68 documents $(62$ articles, 3 book chapters, 2 books and 1 research report). The descriptive analysis of the material was carried out by identifying the discipline and country of the first author and the year of publication. The corpus of documents was characterised by a strong interdisciplinary nature. Fifteen social and human sciences disciplines are represented, the more frequent of which were psychology, sociology, law, gender studies, education and human resources/organisational studies. Concerning the geographical contexts, more than half came from AngloSaxon countries $(\mathrm{N}=47)$, mainly the United States. A number of documents came from Latin America $(\mathrm{N}=11)$, particularly Brazil and Argentina. Continental Europe and Asian countries were also represented $(\mathrm{N}=8$ and $\mathrm{N}=2$ respectively). The year of publication indicated an increase in the number of articles in the last three years, with more than half of the selected documents published from 2014 to $2016(\mathrm{~N}=37)$.

The methodology used for analysing the corpus was qualitative content analysis (Andréu Abela, 2000). Content analysis is a text interpretation technique that can be applied to any type of data record and uses codes as the fundamental element to describe the characteristics of the data content. It aims at systematising and explaining the content of texts with the help of hints, quantifiable or not.

I looked for explicit definitions of trans people and associated terminology in each document and employed an inductive approach for identifying themes within the definitions. Using software for qualitative data analysis (ATLAS.ti 7 for Windows), I attributed codes to units of meaning in a process of coding and recoding to define the themes. Eight themes 
were identified in the definitions and different terms were used to refer to different combinations of themes. Results are described in detail in the next section.

\section{Results: Trans terminology and definitions}

Eight themes were identified in the definitions of trans people: identity, expression, sex-gender binary, man-woman binary, body modifications, medical diagnosis, antipathological claim and political claim. Most of the definitions combine two or more of these themes. The same term is sometimes used to refer to different definitions. Some documents did not include any explicit definition of trans people $(\mathrm{N}=22)$. See table 2 for a summary.

The identity theme defines trans people as people whose gender identity is different to the category assigned at birth. The birthassigned category is sometimes denominated 'sex' and sometimes 'gender', indicating a conflation of the two terms in the literature.

A second theme found in the definitions is the expression. This refers to a physical appearance and/or behaviour differing from the traditional expressions associated with the gender category assigned at birth.

The notion of the gender binary is used with two different meanings (third and fourth themes). On the one hand, some definitions use the notion to refer to the sex-gender binary, i.e. the idea that there is a correspondence between the gender category and biological sex, and the extent to which trans people challenge it. On the other hand, some definitions stress the fact that certain trans people do not see themselves as either man or woman, negating the notion that gender is a binary category (man-woman binary).

Terminology is used in different ways to emphasise different combinations of identity, expression and gender binary themes. In relation to the second meaning of gender binary, the term 'transsexual' is sometimes used to refer to people who see themselves as men or women, whereas 'transgender', 'genderqueer' or 'trans people' are used to refer to people who do not see themselves within those binary themes. However, on other occasions 'transgender' and 'trans people' are used as an umbrella term to include transsexual people.

Used as umbrellas, the terms 'transgender' (especially in Anglo-Saxon and Frenchspeaking contexts) and 'trans people' (especially in Spanish and Portuguese) usually refer to people whose gender identity and/or expression differ from the gender category assigned at birth. Overall, these definitions emphasise the first meaning of the notion of binary: trans people as a challenge to the notion that gender categories stem from biological sex. In the same vein, the term 'cisgender' is used as the opposite of transgender/trans, defining people whose gender identity corresponds to the gender category assigned at birth.

Although in many definitions the identity and expression themes are combined, a distinction is sometimes made, with certain definitions focusing exclusively on the expression theme to define trans people as a transgression of the traditional gender expression associated with the assigned gender at birth, irrespective of whether the person identifies as trans or not. In this sense, the nature of discrimination will not be seen in connection with a particular identity, but rather with how the person is perceived. The terminology used to refer to the expression theme alone is usually 'gender non-conforming', 'gender non-conformers' and 'crossdresser'. However, 'gender non-conforming' is sometimes also used as an umbrella term.

A fifth theme in the definitions relates to whether there have been body modifications or whether there is a wish to undergo such, be it hormonal and/or surgical. In this sense, 'transsexual' is sometimes used to designate people who have undergone or wish to undergo body surgery, whereas 'transgender' (in English and French) and 'travesti' (in Spanish and Portuguese) are used to designate people who do not wish to do so.

A sixth theme is the psychiatric diagnosis. Although a minority theme in the consulted literature, two authors use the definitions of the Diagnostic of Statistical Manual of Mental Disorders (American Psychiatric Association) and the International Classification of Diseases (World Health Association). Such definitions characterise trans experiences as a mental disorder and/or as a dysphoria. 


\begin{tabular}{|c|c|c|}
\hline Theme & Terminology & Document \\
\hline Identity & $\begin{array}{l}\text { Transgender, transsexual, trans, } \\
\text { trans*, transpeople, transgendered } \\
\text { (vs. cisgender) }\end{array}$ & $\begin{array}{l}\text { Adrian, (2013); Ali, Fleisher, \& Erickson (2016); Ansara \& Hegarty (2012); Broockman \& } \\
\text { Kalla (2016); Brower (2016); Buist \& Stone (2014); Collins, McFadden, Rocco, \& Mathis } \\
\text { (2015); Cruz (2014); Curtis (2016); Davis (2014); Dietert \& Dentice (2015); Erni (2013); } \\
\text { Gazzola \& Morrison (2014); Gerhardstein \& Anderson (2010); Grigoropoulos \& Kordoutis } \\
\text { (2015); King, Winter, \& Webster (2009); Nadal, Skolnik, \& Wong (2012); Norton \& } \\
\text { Herek (2013); Sawyer, Thoroughgood, \& Webster (2016); Suess (2014); E. A. Tebbe, } \\
\text { Moradi, \& Ege (2014); Tee \& Hegarty (2006); Walch, Ngamake, Francisco, Stitt, \& Shin- } \\
\text { gler (2012); Winter (2009); Worthen (2016) }\end{array}$ \\
\hline Expression & $\begin{array}{l}\text { Transgender, transsexual, gender } \\
\text { nonconforming, cross dresser, } \\
\text { travesti, trans, trans*, } \\
\text { transgendered } \\
\text { (vs. cisgender) }\end{array}$ & $\begin{array}{l}\text { Adrian (2013); Collins et al. (2015); Cruz (2014); Curtis (2016); Dietert \& Dentice } \\
\text { (2015); Erni (2013); Gazzola \& Morrison (2014); Gerhardstein \& Anderson (2010); } \\
\text { Grigoropoulos \& Kordoutis (2015); Hill \& Willoughby (2005); Huffaker \& Kwon (2016); } \\
\text { Moulin de Souza \& de Pádua Carrieri (2015); Norton \& Herek (2013); Rottenbacher de } \\
\text { Rojas (2012); Suess (2014); E. A. Tebbe et al. (2014); Walch, Ngamake, et al. (2012) }\end{array}$ \\
\hline $\begin{array}{l}\text { Sex-gender } \\
\text { binary }\end{array}$ & $\begin{array}{l}\text { Transgender, transsexual, trans, } \\
\text { queer, gender nonconforming, } \\
\text { cross dresser, trans*, } \\
\text { transgendered } \\
\text { (vs. cisgender) }\end{array}$ & $\begin{array}{l}\text { Adrian (2013); Begun \& Kattari (2016); Bettcher (2007); Broockman \& Kalla (2016); } \\
\text { Brower (2016); Buist \& Stone (2014); Collins et al. (2015); Connell (2010); Cruz (2014); } \\
\text { Curtis (2016); Davis (2014); Dietert \& Dentice (2015); Erni (2013); Franco \& Cicillini } \\
\text { (2015); Gazzola \& Morrison (2014); Gerhardstein \& Anderson (2010); Grigoropoulos \& } \\
\text { Kordoutis (2015); Huffaker \& Kwon (2016); King et al. (2009); Lehtonen (2016); Missé \& } \\
\text { Coll-Planas (2010); Morán Faúndes (2015); Moulin de Souza \& de Pádua Carrieri (2015); } \\
\text { Nadal et al. (2012); Nagoshi et al. (2008); Norton \& Herek (2013); Schilt \& Westbrook } \\
\text { (2009); Stefanes Pacheco \& Stefanes Pacheco (2016); Suess (2014); Tebbe et al. (2014); } \\
\text { Tee \& Hegarty (2006); Walch, Sinkkanen, et al. (2012); Walch, Ngamake, et al. (2012); } \\
\text { Warriner, Nagoshi, \& Nagoshi (2013); Worthen (2016) }\end{array}$ \\
\hline $\begin{array}{l}\text { Man-woman } \\
\text { binary }\end{array}$ & $\begin{array}{l}\text { a) No within binary: } \\
\text { Transgender, gender nonconform- } \\
\text { ing, gender variant, queer, traves- } \\
t i \text { genderqueer, trans } \\
\text { b) Within binary: } \\
\text { Transsexual, MtF, FtM }\end{array}$ & $\begin{array}{l}\text { Brower (2016); Connell (2010); Cruz (2014); Davis (2014); Franco \& Cicillini (2015); Mis- } \\
\text { sé \& Coll-Planas (2010); Morán Faúndes (2015); Moulin de Souza \& de Pádua Carrieri } \\
\text { (2015); Páez, Hevia, Pesci, \& Rabbia (2015) }\end{array}$ \\
\hline $\begin{array}{c}\text { Body } \\
\text { modifications }\end{array}$ & $\begin{array}{l}\text { a) Body modifications: } \\
\text { Transsexual, MTF, FTM } \\
\text { b) No body modifications: } \\
\text { Transgender, cross dresser, } \\
\text { transgenderist, travesti, gender } \\
\text { nonconforming }\end{array}$ & $\begin{array}{l}\text { Dietert \& Dentice (2015); Erni (2013); Gerhardstein \& Anderson (2010); Hill \& } \\
\text { Willoughby (2005); Huffaker \& Kwon (2016); King et al. (2009); Missé \& Coll-Planas } \\
\text { (2010); Moulin de Souza \& de Pádua Carrieri (2015); Nadal et al. (2012); Nagoshi et al. } \\
\text { (2008); Norton \& Herek (2013); Rottenbacher de Rojas (2012); Walch, Sinkkanen, et al. } \\
\text { (2012); Walch, Ngamake, et al. (2012) }\end{array}$ \\
\hline $\begin{array}{c}\text { Psychiatric } \\
\text { diagnosis }\end{array}$ & Transsexual & Barclay \& Scott (2006) \\
\hline $\begin{array}{l}\text { Anti- } \\
\text { pathologisation } \\
\text { claim }\end{array}$ & $\begin{array}{l}\text { Transgender (vs. transsexual), } \\
\text { gender variant individuals, trans- } \\
\text { sexual, travesti }\end{array}$ & $\begin{array}{l}\text { Adrian (2013); Ansara \& Hegarty (2012); Bento \& Pelúcio (2012); Bettcher (2007); Con- } \\
\text { nell (2010); Erni (2013); Lasso Báez (2014) }\end{array}$ \\
\hline Political claim & $\begin{array}{l}\text { Transgender, queer, genderqueer, } \\
\text { trans, } \mathrm{Ft}^{*}, \mathrm{Mt}^{*}\end{array}$ & $\begin{array}{l}\text { Bailey (2011); Franco \& Cicillini (2015; Huffaker \& Kwon (2016); Nadal et al. (2012); } \\
\text { Norton \& Herek (2013) }\end{array}$ \\
\hline $\begin{array}{l}\text { No explicit } \\
\text { definition }\end{array}$ & $\begin{array}{l}\text { Transsexual, trans people, } \\
\text { transgender, travesti, FTM } \\
\text { transsexuals, trans }\end{array}$ & $\begin{array}{l}\text { Alessandrin (2016); Case \& Stewart (2013); Currah (2008); Dean, Victor, \& Grimes } \\
\text { (2016); DePalma \& Jennett (2010); Dierckx, Motmans, \& Meier (2014); Formby (2015); } \\
\text { Gilbert (2009); Loutzenheiser (2015); McFadden (2015); Meadow (2010); Molina } \\
\text { Rodríguez et al. (2015); Myers (2010); Ozeren, Ucar, \& Duygulu (2016); Priola, Lasio, } \\
\text { De, \& Serri (2014); Rasmussen, Sanjakdar, Allen, Quinlivan, \& Bromdal (2015); Resende } \\
\text { Alves \& Costa Moreira (2015); Riggs (2014); Schilt (2006); Spade (2015); E. N. Tebbe \& } \\
\text { Moradi (2012); Willoughby et al. (2010) }\end{array}$ \\
\hline
\end{tabular}

Table 2. Themes, associated terminology and document(s) in which they appeared

'Transsexual' is the term used when a medical diagnosis definition is provided.

The seventh theme, the anti-pathologisation claim, is intimately related to the previous one. The term 'transgender' is used in this sense to show a resistance to the medical pathologisation of trans people, traditionally associated with the term 'transsexual'.
The last theme highlights the notion that identity is not fixed and static, but fluid and changeable over time. It underlines a political claim against essentialist and static views of identity and gender categories and calls for a more flexible perspective on gender. 'Genderqueer', 'trans' and 'transgender' are terms used to denote this political claim. 
Finally, some documents did not provide any explicit definition of trans people. In most cases this was due to the fact that the object of study was the construction itself of gender norms and categories. In some other cases the term 'transgender' was used as an umbrella for a range of terms without providing a conceptual definition. In a few cases the definition seemed to be taken for granted.

\section{Discussion and conclusions}

The results of the analysis highlight the complexity of defining trans people and hence, the difficulty in studying transphobia and discrimination against them. In this section, some implications of this complexity are discussed.

The definition of trans people emerges as an important issue for research in two ways. On the one hand, the multiplicity of terms and their polysemy represent a challenge for studies focusing on trans people as an enduring, preformed entity. This is the case with research into attitudes towards trans people, where the name of the category is used in questionnaires with close-ended questions. For instance, if the item is 'I am fearful of transsexuals' (Case \& Stewart, 2013, p. 146), it can be complicated - if not impossible - to know what people actually understand under the term 'transsexual' (or any other trans terms). As the analysis shows, there is a wide range of trans-related terms that are used in different ways to stress diverse defining themes key to understanding discrimination against trans people. It is therefore difficult to discern the exact target of the (negative) attitude. As Patricia Elliot (2009) points, the issue at stake in the different terms and definitions of trans people is the different ways to think about and to live gender variance that result in different experiences of exclusion and discrimination. In this sense, examining attitudes towards gender norms seems more helpful than focusing on attitudes towards the category itself.

On the other hand, the very definition of trans people seems to be at the root of discrimination and thus a discursive battleground. This battle is manifested, for instance, in trans people's struggle against the pathologising definition of their identities and experiences. The definition of a social cate- gory both describes and constitutes the category, and has implications for the way in which we understand the social world (Potter \& Wetherell, 1987; Stainton Rogers, 2003). According to Jack Halberstam (2017), there seems to be a deep desire to stabilise the category 'trans'. However, this can be problematic because clear-cut definitions of trans people convey the notion that trans and cisgender people are different kinds of people (Ansara \& Hegarty, 2012). This takes place, for instance, when the term 'transpeople' (as one word) is used as a name instead of as an adjective (i.e. 'trans people') (Simmons \& White, 2014). It conveys the notion that 'trans' defines the whole identity of a person instead of seeing it as just one of the many characteristics of that person. This can in turn lead to the idea that cisgender people are always on the side of conformity (Ortega, 2015), thereby reducing the problem of discrimination to a minority issue (Simmons \& White, 2014). Furthermore, too often definitions of trans people become established by institutions - such as academia - that have the power to promote descriptions and classifications that may erase the way people selfdefine (Bender-Baird, 2011).

These reflections raise the question of how to flexibly define trans people for research purposes without reproducing clear-cut distinctions between trans and non-trans people. In this sense, I recommend following Bettcher's (2015) argument for leaving the term 'trans people' open to multiple meanings and for offering a minimum definition for research purposes. I consider that this definition should revolve around the notions of bodies and categories. Therefore, I recommend defining trans people as 'people who do not comply with prevailing expectations about gender embodiment to varying degrees and in different ways'. This definition of trans people should be understood as perpetually provisional because, should certain forms of gender embodiment not prevail over others, the distinction between the categories 'trans' and 'non-trans' would lose all sense. This would imply that there would be no robust definition of trans people to study discrimination against them. Instead, I suggest studying how people and institutions themselves define gender norms and gender categories and the consequent implications for trans people in terms of unintelligibility and othering. Relying 
on trans people's self-definitions and accounts of discrimination is also a fruitful way to understand the nature of transphobia.

In conclusion, the terminology and definition used in scientific research on transphobia and discrimination against trans people have important methodological and social implications. In methodological terms, it is important to take into account that trans terminology is not unambiguous and that different issues are at stake in the descriptions of trans people. Studying the constitution of gender norms and categories seems a promising research approach into transphobia. In social terms, it is important to note that research contributes to establishing definitions to understand the social world. In this sense, reflexivity is critically important to identify the meanings produced by research itself.

\section{References}

Adrian, Tamara (2013). Cuadrando El Círculo: Despatologización Vs Derecho a La Salud De Personas Trans En Dsm- 5 Y Cie-11. Comunidad y Salud, 11(1), 58-65.

Alessandrin, Aranud (2016). La transphobie en France: Insuffisance du droit et expériences de discrimination. Cahiers du Genre, 60(1), 193212. https://doi.org/10.3917/cdge.060.0193

Ali, Nareesa; Fleisher, William, \& Erickson, Julie (2016). Psychiatrists' and Psychiatry Residents' Attitudes Toward Transgender People. Academic Psychiatry, 40(2), 268-273. https://doi.org/10.1007/s40596-015-0308-y

Andréu Abela, Jaime (2000). Las técnicas de análisis de contenido: una revisión actualizada. Fundación Centro Estudios Andaluces, Universidad de Granada, 10(2), 1-34.

Ansara, Y. Gabriel, \& Hegarty, Peter (2012). Cisgenderism in psychology: Pathologising and misgendering children from 1999 to 2008. Psychology and Sexuality, 3(2), 137-160. https://doi.org/10.1080/19419899.2011.576696

Bailey, Marlon (2011). Gender/Racial Realness: Theorizing the Gender System in Ballroom Culture. Feminist Studies, 37(2), 365-386.

Barclay, Jean \& Scott, L. (2006). Transsexuals and workplace diversity: A case of "change" management. Personnel Review, 35(4), 487-502. https: / /doi.org/10.1108/00483480610670625

Begun, Stephanie \& Kattari, Shanna K. (2016). Conforming for survival: Associations between transgender visual conformity/passing and home- lessness experiences. Journal of Gay and Lesbian Social Services, 28(1), 54-66.

https://doi.org/10.1080/10538720.2016.1125821

Bender-Baird, Kyla (2011). Transgender employment experiences: Gendered perceptions and the law. Transgender Employment Experiences: Gendered Perceptions and The Law. Albany: State University New York Press.

Bento, Berenice \& Pelúcio, Larissa (2012). Despatologização do gênero: a politização das identidades abjetas. Revista Estudos Feministas, 20(2), 569-581. https://doi.org/10.1590/s0104$\underline{026 \times 2012000200017}$

Bettcher, Talia Mae (2007). Evil Deceivers and Make-Believers: On Transphobic Violence and the Politics of Illusion. Hypatia, 22(3), 43-65. https://doi.org/10.1111/j.15272001.2007.tb01090.x

Bettcher, Talia Mae (2014). Feminist Perspectives on Trans Issues. In Edward N. Zalta (Ed.), The Stanford Encyclopedia of Philosophy (Spring 2014 Edition). Retrieved from:

https://plato.stanford.edu/archives/spr2014/en tries/feminism-trans/

Bettcher, Talia Mae (2015). Transphobia. Transgender Studies Quarterly,1, (1-2), 249-251. https://doi.org/10.1215/23289252-2400181

Broockman, David \& Kalla, Joshua (2016). Durably reducing transphobia: A field experiment on door-to-door canvassing. Science, 352(6282), 220-224.

https://doi.org/10.1126/science.aad9713

Brower, Todd (2016). Visibility and the workplace experiences of trans persons in the United States. In Thomas Köllen (Ed.), Sexual Orientation and Transgender Issues in Organizations: Global Perspectives on LGBT Workforce Diversity (pp. 149-166). Cham: Springer International Publishing.

Buist, Carrie L. \& Stone, Codie (2014). Transgender Victims and Offenders: Failures of the United States Criminal Justice System and the Necessity of Queer Criminology. Critical Criminology, 22(1), 35-47. https://doi.org/10.1007/s10612013-9224-1

Case, Kim A. \& Stewart, Brina (2013). Intervention Effectiveness in Reducing Prejudice Against Transsexuals. Journal of LGBT Youth, 10(1-2), 140-158. https://doi.org/10.1080/19361653.2012.718549

Collins, Joshua C.; McFadden, Ciarán; Rocco, Tonette S. \& Mathis, Mary Katherine (2015). The Problem of Transgender Marginalization and Exclusion: Critical Actions for Human Resource Development. Human Resource Development Re- 
view, 14(2), 205-226.

https: / /doi.org/10.1177/1534484315581755

Connell, Catherine (2010). Doing, Undoing, or Redoing Gender? Learning from the Workplace Experiences of Transpeople. Gender \& Society, 24(1), 31-55.

https: / / doi.org/10.1177/0891243209356429

Cruz, Taylor M. (2014). Assessing access to care for transgender and gender nonconforming people: A consideration of diversity in combating discrimination. Social Science and Medicine, 110, 65-73. https://doi.org/10.1016/j.socscimed.2014.03.03 $\underline{2}$

Currah, Paisley (2008). Expecting Bodies: The Pregnant Man and Transgender Exclusion from the Employment Non-Discrimination Act. Women's Studies Quarterly, 36(3/4), 330-336. https://doi.org/10.1353/wsq.0.0101

Curtis, Aaron J. (2016). Conformity or nonconformity? Designing legal remedies to protect transgender students from discrimination. Harvard Journal on Legislation, 53(2), 460-497.

Davis, Heath Fogg (2014). Sex-classification policies as transgender discrimination: An intersectional critique. Perspectives on Politics, 12(1), 45-60.

https://doi.org/10.1017/s1537592713003708

Dean, Megan A.; Victor, Elisabeth, \& Grimes, Laura G. (2016). Inhospitable Healthcare Spaces: Why Diversity Training on LGBTQIA Issues Is Not Enough. Journal of Bioethical Inquiry, 13(4), 557-570. https://doi.org/10.1007/s11673-0169738-9

DePalma, Renée \& Jennett, Mark (2010). Homophobia, transphobia and culture: Deconstructing heteronormativity in English primary schools. Intercultural Education, 21(1), 15-26. https: / /doi.org/10.1080/14675980903491858

Dierckx, Myrte ; Motmans, Joz, \& Meier, Petra (2014). Beyond the box. Mesure d'attitudes en matière de sexisme, d'homophobie et de transphobie. Bruxelles: Institut pour l'égalité des femmes et des hommes.

Dietert, Michelle \& Dentice, Diane (2015). The Transgender Military Experience: Their Battle for Workplace Rights. Journal of Workplace Rights, 5(2), 1-12.

https: / / doi.org/10.1177/2158244015584231

Doménech, Miquel \& Íñiguez-Rueda, Lupicinio (2002). La construcción social de la violencia. Atenea Digital, 2, 1-10.

https://doi.org/10.5565/rev/athenead/v1n2.54

Elliot, Patricia (2009). Engaging Trans Debates on Gender Variance: A Feminist Analysis. Sexuali- ties, $12,5-32$.

https://doi.org/10.1177/1363460708099111

Erni, John N. (2013). Legitimating Transphobia: The legal disavowal of transgender rights in prison. Cultural Studies, 27(1), 136-159. https://doi.org/10.1080/09502386.2012.722305

Espineira, Karine (2014). La sexualité des sujets transgenres et transsexuels saisie par les médias. Revue Hermès, 69(2), 105-109.

European Union Agency for Fundamental Rights (2014). Being Trans in the European Union. Comparative analysis of EU LGBT survey data. Luxembourg: Publications Office of the European Union.

Formby, Eleanor (2015). Limitations of focussing on homophobic, biphobic and transphobic 'bullying' to understand and address LGBT young people's experiences within and beyond school. Sex Education, 15(6), 626-640.

https://doi.org/10.1080/14681811.2015.1054024

Franco, Neil \& Cicillini, Graça Aparecida (2015). Professoras trans brasileiras em seu processo de escolarização. Revista Estudos Feministas, 23(2), 325-346. http://dx.doi.org/10.1590/0104026X2015v23n2p325

Gazzola, Stephanie B. \& Morrison, Melanie A. (2014). Cultural and Personally Endorsed Stereotypes of Transgender Men and Transgender Women: Notable Correspondence or Disjunction? International Journal of Transgenderism, 15(2), 76-99.

https: / / doi.org/10.1080/15532739.2014.937041

Gerhardstein, Kelly R. \& Anderson, Veanne N. (2010). There's more than meets the eye: Facial appearance and evaluations of transsexual people. Sex Roles, 62(5-6), 361-373. https://doi.org/10.1007/s11199-010-9746-x

Gilbert, Miqqi Alicia (2009). Defeating Bigenderism: Changing Gender Assumptions in the Twenty-First Century. Hypatia, 24(3), 93-112. https://doi.org/10.1111/j.1527$\underline{2001.2009 .01047 . x}$

Grigoropoulos, Iraklis \& Kordoutis, Pannos (2015). Social Factors Affecting Antitransgender Sentiment in a Sample of Greek Undergraduate Students. International Journal of Sexual Health, 27(3), 276-285.

https://doi.org/10.1080/19317611.2014.974792

Halberstam, Jack (2017). Trans* Bodies. Lecture by Jack Halberstam. Barcelona: CCCB Multimedia Archive.

Hill, Darril B. \& Willoughby, Bryan L. B. (2005). The development and validation of the genderism and transphobia scale. Sex Roles, 53(7-8), 
531-544. https: //doi.org/10.1007/s11199-005$\underline{7140-x}$

Huffaker, Laena \& Kwon, Paul (2016). A comprehensive approach to sexual and transgender prejudice. Journal of Gay and Lesbian Social Services, 28(3), 195-213. https://doi.org/10.1080/10538720.2016.1191405

King, Mark E., Winter, Sam, \& Webster, Beverly (2009). Contact reduces transprejudice: A study on attitudes towards transgenderism and transgender civil rights in Hong Kong. International Journal of Sexual Health, 21(1), 17-34. https: / / doi.org/10.1080/19317610802434609

Lasso Báez, Roberto A. (2014). Transexualidad y servicios de salud utilizados para transitar por los sexos-géneros. CES Psicología, 7(2), 108-125.

Lehtonen, Jukka (2016). Experiences of nonheterosexual and trans youth on career choice and in the workplace. In Thomas Köllen (Ed.), Sexual Orientation and Transgender Issues in Organizations: Global Perspectives on LGBT Workforce Diversity (pp. 289-306). Cham: Springer International Publishing.

Loutzenheiser, Lisa W. (2015). 'Who are you calling a problem?': addressing transphobia and homophobia through school policy. Critical Studies in Education, 56(1), 99-115. https://doi.org/10.1080/17508487.2015.990473

Martínez-Guzmán, F. Antar (2015). Las nuevas categorías sexuales y la psicología del sujeto como 'empresario de sí': un análisis sobre los dilemas de la disidencia sexogenérica en el contexto neoliberal. Universitas Psychologica, 14(5), 15391550.

https: / / doi.org/10.11144/javeriana.upsy145.ncsp

McFadden, Ciarán (2015). Lesbian, Gay, Bisexual, and Transgender Careers and Human Resource Development: A Systematic Literature Review. Human Resource Development Review, 14(2), 125-162.

https: / /doi.org/10.1177/1534484314549456

Meadow, Tey (2010). "A Rose is a Rose” On Producing Legal Gender Classifications. Gender \& Society, 24(6), 814-837.

https://doi.org/10.1177/0891243210385918

Missé, Miquel \& Coll-Planas, Gerard (2010). El género desordenado. Críticas entorno a la patologización de la transexualidad. Barcelona-Madrid: Editorial Egales.

Molina Rodríguez, Nancy. E., Guzmán Cervantes, Oscar O. \& Martínez-Guzmán, Antar (2015). Identidades transgénero y transfobia en el contexto mexicano: Una aproximación narrativa. Quaderns de Psicologia, 17(3), 71-82.

https://doi.org/10.5565/rev/qpsicologia.1279
Morán Faúndes, José Manuel (2015). Géneros, transgéneros: hacia una noción bidimensional de la injusticia. Andamios. Revista de Investigación Social, 12(27), 257-278.

https://doi.org/10.29092/uacm.v12i27.84

Moulin de Souza, Eloisio \& de Pádua Carrieri, Alexandre (2015). When Invisibility Is Impossible: Body, Subjectivity, and Labor Among Travestis and Transsexuals. Journal of Workplace Rights, 5 (2), 1-11.

https: / /journals.sagepub.com/doi/10.1177/2158 $\underline{244015585406}$

Myers, Polly R. (2010). Jane Doe v. Boeing Company: Transsexuality and Compulsory Gendering in Corporate Capitalism. Feminist Studies, 36(3), 493-517.

https: / /doi.org/10.2307/j.ctt1d98b62.10

Nadal, Kevin L., Skolnik, Avy \& Wong, Yinglee (2012). Interpersonal and systemic microaggressions toward transgender people: Implications for counseling. Journal of LGBT Issues in Counseling, 6(1), 55-82.

https: / / doi.org/10.1080/15538605.2012.648583

Nagoshi, Julie L., Adams, Katherine A., Terrell, Heather. K., Hill, Eric D., Brzuzy, Stephanie \& Nagoshi, Craig T. (2008). Gender differences in correlates of homophobia and transphobia. Sex Roles, 59(7-8), 521-531.

https://doi.org/10.1007/s11199-008-9458-7

Norton, Aaron T. \& Herek, Gregory M. (2013). Heterosexuals' Attitudes Toward Transgender People: Findings from a National Probability Sample of U.S. Adults. Sex Roles, 68(11-12), 738-753. https://doi.org/10.1007/s11199-011-0110-6

Ortega, Julián (2015). Derechos sexuales en el mundo del trabajo: Hacia la promoción de las diversidades sexo-genéricas en contextos organizacionales públicos y privados de argentina. Anuario de Investigaciones, 22, 71-79.

Ozeren, Emir, Ucar, Zeki \& Duygulu, Ethem (2016). Silence speaks in the workplace: Uncovering the experiences of LGBT employees in Turkey. In Thomas Köllen (Ed.), Sexual Orientation and Transgender Issues in Organizations: Global Perspectives on LGBT Workforce Diversity (pp. 217232). Cham: Springer International Publishing.

Páez, José, Hevia, Guillermo, Pesci, Florencia \& Rabbia, Hugo (2015). Construcción y validación de una escala de actitudes negativas hacia personas trans. Revista de Psicología, 33(1), 151188.

Platero Méndez, R. Lucas (2014). Trans*exualidades: Acompañamiento, factores de salud y recursos educativos. Barcelona: Edicions Bellaterra. 
Potter, Jonathan \& Wetherell, Margaret (1987). Discourse and Social Psychology. Beyond attitudes and behaviour. London: SAGE.

Priola, Vicenza, Lasio, Diego, De Simone, Silvia \& Serri, Francesco (2014). The Sound of Silence. Lesbian, Gay, Bisexual and Transgender Discrimination in "Inclusive Organizations." British Journal of Management, 25(3), 488-502. https://doi.org/10.1111/1467-8551.12043

Rasmussen, Mary Lou, Sanjakdar, Fida, Allen, Louisa, Quinlivan, Kathleen \& Bromdal, Annette (2015). Homophobia, transphobia, young people and the question of responsibility. Discourse: Studies in the cultural politics of education, 38(1), 30-42.

https: / / doi.org/10.1080/01596306.2015.1104850

Resende Alves, Claudio E. \& Costa Moreira, Maria I. (2015). Do uso do nome social ao uso do banheiro: (trans)subjetividades em escolas brasileiras. Quaderns de Psicologia, 17(3), 59-69. https: //doi.org/10.5565/rev/apsicologia.1275

Riggs, Damien W. (2014). What makes a man? Thomas Beatie, embodiment, and "mundane transphobia." Feminism and Psychology, 24(2), 157-171.

https: / / doi.org/10.1177/0959353514526221

Rottenbacher de Rojas, Jan Marc (2012). Conservadurismo político, homofobia y prejuicio hacia grupos transgénero en una muestra de estudiantes y egresados universitarios de Lima. Pensamiento Psicológico, 10(1), 23-37.

Sawyer, Katina, Thoroughgood, Christian \& Webster, Jennica (2016). Queering the gender binary: Understanding transgender workplace experiences. In Thomas Köllen (Ed.), Sexual Orientation and Transgender Issues in Organizations: Global Perspectives on LGBT Workforce Diversity (pp. 21-42). Cham: Springer International Publishing.

Schilt, Kristen (2006). Just One of the Guys? How Transmen Make Gender Visible at Work. Gender \& Society, 20(4), 465-490. https: / /doi.org/10.1177/0891243206288077

Schilt, Kristen \& Westbrook, Laurel (2009). Doing Gender, Doing Heteronormativity: "Gender Normals," Transgender People, and the Social Maintenance of Heterosexuality. Gender and Society, 23(4), 440-464.

https: / /doi.org/10.1177/0891243209340034

Seuring, Stefan, Müller, Martin, Westhaus, Magnus \& Morana, Romy (2005). Conducting a Literature Review - The Example of Sustainability in Supply Chains. In Herber Kotzab, Stefan Seuring, Martin Müller and Gerald Reiner (Eds.), Research Methodologies in Supply Chain Management (pp. 91106). Heidelberg: Physica-Verlag HD.
Simmons, Holiday \& White, Freshi (2014). Our many selves. In Laura Erickson-Schroth (Ed.), Trans Bodies, Trans Selves. A resource for the transgender community ( pp. 3-23). New York: Oxford University Press.

Spade, Dean (2015). Normal Life: Administrative Violence, Critical Trans Politics and the Limits of Law. Durham: Duke University Press.

Stainton Rogers, Wendy (2003). Social Psychology. Experimental and critical approaches. Philadelphia: Open University Press.

Stefanes Pacheco, Rosely Aparecida \& Stefanes Pacheco, Isabela (2016). Direito, violências e sexualidades: a transexualidade em um contexto de direitos. Revista Estudios Socio-Jurídicos, 18(2), 201-226.

https://doi.org/10.12804/esj18.02.2016.07

Stryker, Susan \& Whittle, Stephen (2006). The Transgender Studies Reader. New York: Routledge.

Suess, Amets (2014). Cuestionamiento de dinámicas de patologización y exclusión discursiva desde perspectivas trans e intersex. Revista de Estudios Sociales, 49, 128-143. https: / /doi.org/10.7440/res49.2014.10

Tebbe, Esther A., Moradi, Bonnie \& Ege, Engin (2014). Revised and abbreviated forms of the genderism and transphobia scale: Tools for assessing anti-trans* prejudice. Journal of Counseling Psychology, 61(4), 581-592. https://doi.org/10.1037/cou0000043

Tebbe, Esther N. \& Moradi, Bonnie (2012). Antitransgender prejudice: a structural equation model of associated constructs. Journal of counseling psychology, 59(2), 251-261. https://doi.org/10.1037/e702692011-001

Tee, Nicola \& Hegarty, Peter (2006). Predicting opposition to the civil rights of trans persons in the United Kingdom. Journal of Community and Applied Social Psychology, 16(1), 70-80. https://doi.org/10.1002/casp.851

Transgender Europe (2016, May 12). Already 100 reported murders of trans people in 2016 [Press release]. Retrieved from https: / transrespect.org/en/idahot-2016-tmmupdate/

Walch, Susan E., Ngamake, Sakkaphat T., Francisco, Jacqueline, Stitt, Rashunda L. \& Shingler, Kimberly A. (2012). The attitudes toward transgendered individuals scale: Psychometric properties. Archives of Sexual Behavior, 41(5), 1283-1291. https://doi.org/10.1007/s10508-0129995-6

Walch, Susan. E., Sinkkanen, Kimberly A., Swain, Elisabeth M., Francisco, Jacqueline, Breaux, Cas- 
sie A. \& Sjoberg, Mary D. (2012). Using Intergroup Contact Theory to Reduce Stigma Against Transgender Individuals: Impact of a Transgender Speaker Panel Presentation. Journal of Applied Social Psychology, 42(10), 2583-2605.

https://doi.org/10.1111/j.15591816.2012.00955.x

Warriner, Katrina, Nagoshi, Craig T. \& Nagoshi, Julie L. (2013). Correlates of Homophobia, Transphobia, and Internalized Homophobia in Gay or Lesbian and Heterosexual Samples. Journal of Homosexuality, 60(9), 1297-1314. https://doi.org/10.1080/00918369.2013.806177

Willoughby, Brian L. B., Hill, Dsril B., Gonzalez, Cesar A., Lacorazza, Alessandra; Macapagal, Raymond A., Barton, Michelle E. \& Doty, Nathan
D. (2010). Who hates Gender outlaws? A multisite and multinational evaluation of the Genderism and Transphobia Scale. International Journal of Transgenderism, 12(4), 254-271.

https://doi.org/10.1080/15532739.2010.550821

Winter, Sam (2009). Lost in transition: Transpeople, transprejudice and pathology in Asia. International Journal of Human Rights, 13(2-3), 365390.

https: / / doi.org/10.1080/13642980902758200

Worthen, Meredith G. F. (2016). Hetero-cisnormativity and the gendering of transphobia. International Journal of Transgenderism, 17(1), 31-57.

https://doi.org/10.1080/15532739.2016.1149538

\section{SARA AgUiRRE-SÁnCHEZ-BEATO}

Sara Aguirre-Sánchez-Beato is a PhD researcher at the Université libre de Bruxelles (ULB). Her research interests include gender and transgender issues; discrimination; intersectionality; social change; and qualitative methods in psychology. She is a member of the ULB gender and sexuality research structure STRIGES and the Equality Law Clinic. She also collaborates with LAICOS IAPSE (Universitat Autònoma de Barcelona).

\section{DIRECCIÓN DE CONTACTO}

saguirre@ulb.ac.be

\section{FORMATO DE CITACIÓN}

Aguirre-Sánchez-Beato, Sara (2018).Trans Terminology and Definitions in Research on Transphobia: A conceptual review. Quaderns de Psicologia, 20(3), 295-305.

http://dx.doi.org/10.5565/rev/qpsicologia.1453

\section{HISTORIA EDITORIAL}

Recibido: 25/03/2018

Aceptado: 14/11/2018 